\title{
Research on the Impact of the Information Society in the Global South: An Introduction to SIRCA
}

\author{
Arul Chib
}

The age of globalisation has been defined in terms of access to modern information and communication technologies (ICTs) by some scholars (Hutton and Giddens 2001; Castells 2000; Rantanen 2001). Scholarly debate about the role of ICTs as an agent of social organisation and transformation has raged on before and since, from discussions about the networked information society (Bell 1999; Castells 1996) and consideration about the commercial potential of the technology (Gandy 2002; Shapiro and Varian 1999) to critiques of the systemic divides in organisation, access, use, adaptation and impact (Mansell 1999; Norris 2001; Warschauer 2003). Since these initial considerations, we find ourselves living in a world where ICTs have diffused widely to far-flung corners of the globe and are being deployed to confront some of the world's most complex problems. Scholarly debates in domains such as the global digital divide continue, in which some argue that technologies such as mobile phones have led to the expansion of socio-economic opportunity for the developing world (Donner 2008; Waverman et al. 2005), to those who claim that inequalities remain, with resultant limitations on their societal impact (Carmody 2013; Hilbert 2014). We focus here on notions of the impact of ICTs on international development, going beyond issues of access and use, well documented elsewhere.

As the current Millennium Development Goals (MDGs) approach the initial deadline of 2015, it is timely to take stock of the impact these technologies have had on key development problems. This moment is simultaneously the culmination of the second round of SIRCA II (the Strengthening Information Society Research Capacity Alliance), a capacity-building programme for information society research in the context of development in the Global South. It is then worthwhile too to interrogate the impact of research endeavours on the development process.

\footnotetext{
A. Chib, Ph.D. ( $\triangle)$

Wee Kim Wee School for Communication and Information, Nanyang Technological University, Singapore

e-mail: ArulChib@ntu.edu.sg
}

A. Chib et al. (eds.), Impact of Information Society Research in the Global South, DOI 10.1007/978-981-287-381-1_1 


\section{History}

As this volume is the second in a series resulting from the SIRCA programme (see Chib and Harris 2012), it is probably worthwhile to introduce our new readers to the historical trajectory and source for some of the arguments presented here. The IDRC team of Sinha et al. (2012) notes that the programme was borne out of a need for offering institutional support for interdisciplinary and methodologically sound projects led by emerging researchers with mentorship of senior researchers. Among the myriad challenges faced by the discipline were difficulties in measuring development outcomes (and impact), accompanied by an excessive reliance of anecdotal evidence (Gomez and Pather 2012). The lack of adequate scientific documentation and analysis of failures and successes culminated in limited relevance of the research to both practitioners and policymakers (Harris and Chib 2012). A further systemic problem identified was the lack of voice in the research dialogue of researchers from developing countries, possibly as a result of insufficient resources and training (both in quantity and quality) and unsupportive local research environment due to political, structural and other reasons.

These issues were identified as a result of a programme for informed and systematic' research based in Asia which began in 2006 and continued in a workshop at Manila in 2007, culminating in among other endeavours, the launch of the Strengthening ICTD Research Capacity in Asia programme (SIRCA I) in 2008. SIRCA I aimed to address issues related to the limitations in rigour, interdisciplinary research and collaboration in ICTD research, via a research capacity-building programme for emerging scholars in Asia. The programme provided research grants and training opportunities, with a key component being the mentorship of senior researchers provided for 15 emerging principal investigators from Bangladesh (2 projects), Cambodia (2), China, India (4), the Philippines (2), Singapore, Sri Lanka, Thailand and Vietnam. SIRCA was conceived, managed and continues to be implemented by the Singapore Internet Research Centre (SiRC), based at Nanyang Technological University in Singapore. For more details see Chib and Harris (2012)_Linking research to practice: Strengthening ICT for Development research capacity in Asia.

At the end of the three-year SIRCA I programme, emerging researchers produced research outputs such as publications in internationally recognised forums such as journals (including Media Asia Journal and International Journal on Advances in ICT for Emerging Regions), books and conferences (including IFIP WG9.4 Conference 2011, the 5th Annual ACRON-REDECOM conference and the 4th International Conference on Theory and Practice of Electronic Governance (ICEGOV2010)), admission and scholarships to prestigious doctoral programmes and assumption of leadership positions at universities and organisations related to individual disciplines (see SIRCA Technical Report available at www.sirca.org. $\mathrm{sg}$ ). A key question that troubled us at the time concerned whether the impact of the programme related to the personal academic achievements and outputs of the beneficiaries (a measurable output for the programme) or whether there was any 
influence on the broader practices and policies of the day, a view echoed by others (Elder et al. 2013). One conclusion was that the 'SIRCA programme is moving towards a roadmap for navigating the tortuous route from research to impact via practice' (Harris and Chib 2012, p. 9). The attempt to improve methodological rigour via programme activities and mentoring nonetheless left us short of demonstrable compelling evidence of socio-economic impacts, despite providing a range of lessons and research findings shared with the broader community, i.e., academic impact. A key barrier in bridging these two sets of impact, i.e., socio-economic and academic, identified by Harris and Chib (2012) was in the differential processes, skill sets and motivations required of researchers trained in academic investigation. A series of measures were proposed, including greater engagement with a wider range of stakeholders, development of fresh skill sets, a reorientation of internal systems and incentives and production of a different range of outputs.

While I recognise the inherent contradiction of reporting on the impact of ICTs on broad measures of development in yet another (hardly a different output) academic publication, this volume is nevertheless a result of the exhortations to ourselves in the previous avatar of the programme. The SIRCA II (the Strengthening Information Society Research Capacity Alliance) programme was born in 2011, continuing research capacity-building efforts focused on the information society with an expanded global scope, establishing connections between African, Asian and Latin American researchers. The mentorship model evolved from the original hierarchical knowledge delivery model to emphasise the aspect of bidirectional collaborative learning and experience-sharing for both established and emerging researchers. Finally, to manage the complexities of a programme with global reach, SiRC partnered with the University of Western Cape (UWC), ${ }^{1}$ South Africa, and Instituto de Estudios Peruanos (Institute of Peruvian Studies-IEP), Peru, allowing collaboration with my co-editors, Julian May and Roxana Barrantes, based at these respective institutions.

\section{Conceptual Focus}

Beyond the administrative management of an enlarged global scale, the most important aspect of the evolution of the SIRCA II programme has been the focus on an investigation of impact, defined more broadly than economic advancement. The notion of impact emerged from discussions among a variety of stakeholders in the SIRCA process - the donors, reviewers, advisors and the scholars themselves. For example, one key difference versus the SIRCA I programme was that selected investigators were selected not just in terms of their potential for scholarship, but

\footnotetext{
${ }^{1}$ The initial institution of collaboration was University of Kwazulu-Natal (UKZN) based in Durban, South Africa. With the regional collaborator's transfer to UWC, the partnering organisation changed accordingly.
} 
the potential impact of the research on the communities studied was considered as well. We note that impact, even during the process of evaluation of the proposals, was difficult to define, describe or agree upon, leading to contested debates among an interdisciplinary group of senior scholars.

Government rhetoric and media opinion (and more often than not, scholarly tomes) frequently evoke the transformational nature of ICT adoption and use to achieve development goals, with the result that social implications of technology use in the developing world are believed to be enormous. But research indicates that interventions such as the impacts of mobile phone use on marginal communities (Butt and Sarker 2009) and in health care (Chib et al. 2014), e-governance on transparency and openness (Bhatnagar and Singh 2010), etc. all show wide fluctuations in impact. Variations in approach are rife, which means we don't really have the answers we think we have (Heeks 2010).

The first volume of the SIRCA book series (Chib and Harris 2012) questioned whether diffusing the boundaries of academic research into the realm of policy formulation and implementation led to broader impact of information society initiatives. We discussed how to translate theoretical approaches from the ivory tower of academia to real-world practice more consistently. This volume extends and focuses the enquiry into impact-looking closely at the nature of this link between research, practice and policy.

Linking Information Society research to issues of practice and policy first requires the definition of impact within the context of the information society and development. The question of impact has been contentious, and this volume hopes to contribute to that discourse by examining two aspects of the debate:

1. Impact of research: how is the research on ICTs in the Global South playing a role in achieving an information society, through implementation in practice, influence on policy formulation and media coverage for shaping public opinion?

2. Research on impact: what is the evidence of the impact of ICTs on society (i.e. the end objectives of socio-economic development)?

This volume is organised along these two major investigative fault lines. The first section on impact of research addresses dominant and alternative frameworks to evaluate and measure real-world impacts, while the second section on research on impact provides empirical evidence from SIRCA II principal investigators. There are valid reasons behind making these questions salient at this historical juncture. ICTD research has faced criticism for under-reporting of negative results, as well as harbouring a techno-centric or techno-determinist bias (Papert 1987). Although the pre-2015 MDG emphasise the need to leverage on the development potential of ICTs, the impact question has time and again begged for theoretical resolution. After several waves of developmental impact of ICTs which have been equally contested at each stage, this chapter next undertakes a review of the core literature related to trends, linkages and disconnects in impact of ICTD research on policy, public opinion and practice and the research on impact of ICTs on developmental objectives itself. 


\section{SIRCA Projects Situated vis-à-vis Theoretical Literature}

It's vital to disaggregate the term impact prior to examining individual contributions from SIRCA authors. Various scholars, policymakers, international development practitioners and others such as journalists have wrestled with questions of how to consider impact when discussing and studying the role of ICTs in the Global South. Flor, in chapter 'Constructing theories of change for information society impact research', raises the question whether digital access and usage have helped achieve the MDGs. He concludes that despite a decade of research, scholars are still divided over identifying the type of impact ICTs have had on development and poverty. Flor argues that while ICTD programmes have tried to address this question by strengthening capacities of information society researchers, the information society discourse still lacks a comprehensive, universally accepted framework that establishes clear causal links between ICTD interventions and achievement of the MDGs.

Information society scholars have suggested diverse frameworks to provide analytical perspectives as to the what, why and how of ICT utilisation and projects in the Global South. Several frameworks, often grounded in development literature, but also drawing from disciplines such as information science, systems theory, sociology, etc., offer useful insights into how technology may improve human lives and bring social change. The conceptual journey ${ }^{2}$ of impact is illuminated next with evidence on the second question in the form of findings from the research projects of SIRCA II researchers. As my co-editors May and Barrantes ponder in chapter 'Impact of research or research on impact: More than a matter of semantics and sequence', it is worth considering the theoretical contribution of the research that follows.

\subsection{Capabilities Approach}

Sen (1999) proposed the since-mainstreamed framework in response to prevailing discussions on development focused on the bottom line of economic growth. Improvement in human well-being had previously been equated principally with economic growth. Scholars such as Chib (2009) and Kleine (2010) argue that the mainstream impact argument for ICTD had been heavily focused on economic development due to a need to legitimise projects for a donor base. Sen challenged the prevailing notion of development by prioritising individual ability to make choices, layering the baseline of economic growth with broader, more humanistic

\footnotetext{
${ }^{2}$ Note that this chapter is not intended to provide a rigorous review of the impact literature. The objective instead is to discuss relevant conceptual frameworks informing the issue of the impact of ICTs and situate the contributions of SIRCA participants contained within this volume relative to the broader scholarly discussion.
} 
conceptions of capabilities and freedoms. While the framework has allowed more in-depth, diverse theoretical discussions, there has been considerable effort to operationalise the concept in order to make it applicable as a framework for structuring and evaluating ICTD projects.

\subsection{Extensions}

Sen's capability approach has subsequently been modified and expanded. Hatakka and De (2011) presented an ICTD evaluation framework by adopting a participatory evaluation approach (House 1980). These scholars argue that Sen's work does not directly address the issue of ICT usage and development. Instead, technology needs to be understood as a means to development goals (or as an intervention) that, together with supportive aspects, enable or restrict conversion factors that translate into outcomes. What's important here is that it's not the technology that is enabling but whether its use contributes to enabling choices for various stakeholders.

This conceptualisation departs from techno-deterministic models of impact. Technology introduction in itself is meaningless unless non-technological factors are taken into consideration, for example, the role of teachers in an educational technology project. Conversion factors influence both the enablement of teaching and learning as well as the ability of teachers and students to make choices. Olivera et al. (2015), in their chapter '(Un)Balanced conversations: Participatory action research in technology development in peruvian primary schools', examine the value of utilising participatory action research, involving teachers in the technological design process for educational applications developed for Peruvian primary schools. The authors acknowledge that there is a constant challenge to design successful technical solutions that fully deliver intended capabilities (Rodriguez et al. 2012) as these programmes are operating in resource-constrained environments that are further complicated by social, psychological, geographic and cultural differences (Chib and Zhao 2009). To bridge this disparity, they recommend a participatory action research approach that supports iterative data gathering and ongoing technology development that would, ultimately, positively improve teaching and learning in schools in developing counties. Hence, this shifts the project focus to building capacities of key users to bolster the educational infrastructure in which the new technologies are deployed.

There are increasing calls for focusing on noneconomic measures of development, with Gomez and Pather (2012) stating that the ICTD evaluation field has often neglected the intangible aspects of technology projects. May and Diga (2015) review the debate surrounding the connection of ICTs to poverty in chapter 'Progress towards resolving the measurement link between ICT and poverty reduction'. They argue that the measures of poverty in the current literature are not sophisticated enough to capture the complexity of development problems. These scholars propose incorporating participatory approaches and subjective well-being measures to enhance our understanding of the link between ICTs and poverty reduction. 
Gomez and Pather (2012) observe that the corporate sector has focused far better on 'intangible aspects of business benefits [...], such as trust, loyalty and brand improvement in evaluation frameworks,' (p. 4) creating greater awareness of organisational identities and capabilities. The argument is that a greater focus on indirect, intangible benefits (rather than the tangible mentioned above) is necessary to incorporate the 'elusive and ubiquitous nature of ICTD impact measurement' (p. 9). Obviously, it is much more challenging to observe and analyse the intangible. Djane and Ling (2015) in the chapter 'The use of mobile communication in the marketing of foodstuffs in Cote d'Ivoire' find that mobile phones facilitate organisation and communication among large-scale and petite wholesalers embedded within a scattered distribution chain. Nonetheless, the analysis also unearthed the traditional 'Chain of the Grandmother' distribution network and 'African taboos' that limit the role of mobile phones in producing greater efficiencies in the foodstuff distribution system.

\subsection{Empowerment Framework}

Alsop and Heinsohn (2005) focus on individual agency and opportunity structure in achieving development outcomes. For these authors, the existence of choice and the achievement of choice are key measures of the degree of empowerment. Aspects such as empowerment and cohesiveness (McNamara 2003) directly affect people's behaviours and responses (Reimer 2002). Melissa et al. (2015), in their chapter 'The Internet and Indonesian women entrepreneurs: Examining the impact of social media on women empowerment', investigate how going online can boost female entrepreneurship by allowing them to establish and conduct businesses from their homes. These scholars use several indicators to measure empowerment, including those related to both existence and achievement of choice, such as domestic decision-making, access to or control over resources, freedom of movement, economic contribution to the household, appreciation within the household and sense of self-worth. Melissa et al. found that the prevalence of social media boosted gender-preneurship in Indonesia, bringing a wide range of business opportunities and flexibilities in terms of both self-actualization possibilities for women as well as improvement in their socio-economic status.

We note however, with a note of caution, that it is necessary to apply a critical lens when examining impact—while there are intangible benefits, there are also intangible negative consequences that ICT researchers should be aware of. Cruz and Sajo (2015) in the chapter 'Cybersex as affective labour: Critical interrogation of the Philippine ICT framework and the Cybercrime Prevention Act of 2012' explore negative consequences of ICT development - cybersex as an anomalous offshoot of ICT development in the Philippines. These researchers examine the operations of cybersex as a business and its uses of ICT and documented the life histories of cybersex workers to make sense of their work, sexuality and identity. The authors argue that instead of legislating the problem away, there are opportunities 
to understand the creative uses of technology appropriation that are practical and meaningful to cybersex workers. This study provides a deeper understanding of how ICT can both be a tool for exploitation as well as broaden choices and empower the marginalised to be self-reliant in truly trying circumstances.

Gomez and Pather (2012) highlight several other voices in ICTD research, from Parthasaranthy and Srinivasan (2006) and Qureshi (2005), who make strong cases against excessive quantifiable data and modelling that may miss out on noneconomic, micro-level impact, to Taylor and Zhang (2007), who argue that transformation depends not on the presence of infrastructure per se but on the design and implementation contextualised to social, economic and technological environments. Chandwani and De's (2015) chapter 'The institutional dynamics perspective of ICT for health initiatives in India' exemplifies the importance of institutional context in impact assessment of ICT4D initiatives. Chandwani's research on telemedicine interventions in India suggests that one of the major behavioural reasons hindering the diffusion of telemedicine (and, by extension, similar ICTD projects) is that these interventions focus on modern medical systems, while the rural population, at large, relies on alternate systems of medicine for primary health care.

\subsection{Sustainable Livelihood Framework}

Developed between the 1980s to the 1990s, the framework adopts a multidimensional perspective towards analysing and measuring the socio-economic impact of developmental projects (van Rijn et al. 2012). Specifically, it argues that the livelihood of people is a function of interrelations between tangible and intangible assets (Newton and Franklin 2011). Scoones (1998) argued that sustainable livelihoods could withstand and recover from shocks, maintain and grow in the future while guarding against depletion of natural resources. The framework proposes five capital assets (Carney 1998) that can be observed and measured for the impact of ICTD projects—-human, natural, financial, physical and social—as cornerstones to be observed and measured for the impact of ICTD projects.

\subsection{Choice Framework}

Agency is a key concept in Kleine's (2013) work, which is then related to a resource portfolio. The argument is that social context influences the development of one's personal characteristics and how one gets to exercise agency. The resources listed are material, financial, natural, geographical, human, psychological, information, cultural and social (as social capital); together these allow a systemic analysis of ICTD projects.

Structure, along with agency, forms an essential element for the choice framework. Structural factors include various formal and informal elements of norms such as laws, regulations, culture, policy, institution, processes and culture. These form 
and are embedded in the discourse which contribute to the framework. Structure contributes to the shaping of the individual resource portfolio and can either enhance or limit one's exercise of agency.

The two-pronged approach of 'agency' and 'structure' sounds fine in an abstract conceptual sphere, but how does the approach pan out in practice? Kleine suggests that the choice framework can help development priorities be more participatory, engaging the recipients' interest and considering local and cultural elements into programme formation and implementation. It operationalises Sen's capability approach, linking ICTs as the means which are imbedded in agency and structure which eventually lead to individual choices. The choice framework requires greater work in terms of measurability, as the author admits that it is more easily applicable to individual level than at aggregate meso- or macro-levels.

Bhatnagar and Singh's (2010) assessment of Indian e-Government initiatives examines national-level data, accompanied with fuzzy measurability and myriad complex relationships. The framework identifies key stakeholders and client value by measuring cost to the client of assessing services and their perception of the quality of service and governance. The research question investigates values that can both be monetised and those that are intangible, across multiple stakeholders (beneficiaries, implementation agencies and society), thus requiring a range of methodologies to capture the overall rating for a project's impact.

In the chapter 'An analytical framework to incorporate ICT as an independent variable', Dodel presents an analytical framework based on Selwyn's (2010) 'Impact Assessment Framework' that includes hierarchical stages of ICT involvement—access, usage, appreciation and outcomes—on development. These scholars argue that ICT research would gain greater relevance to non-ICT researchers by including these variables in addition to measures of individual wellbeing. The model was tested on a sample of young Uruguayans, finding that digital skills were a significant influence on their occupational achievements. Supporting such an analysis, Chew et al. (2011) claim that quantitative analysis is more likely to provide rigorous tests of causality. In their study on ICT use in women-run microenterprises, these scholars find a statistically significant, but limited, causal relationship between access to ICTs and business growth. The authors claim that at the macro level, ICTs have had an overall positive impact in terms of economic growth; however, at the micro-level, it is difficult to find such evidence and, in this case, for micro-entrepreneurs, mostly, due to the cost issues in adopting computers. These examples underscore the challenges of validating higher-level abstractions with measurable empirical evidence-conceptual frames that can bridge local and national-level projects.

\subsection{RAPID (Research and Policy in Development) Programme/Framework}

Young and Court's framework (2004), developed by the Overseas Development Institute, emphasises the link among research, policy and practice. It identifies 
three overlapping areas - the political context, the scientific evidence and the links between policy and research communities-and external context as the factors which will need to be accounted for if research is contribution to the way that policymakers and practitioners work.

Echoing the importance of political context, Ordóñez (2015) in the chapter 'A new set of questions: ICT4D research and policy' suggests that there is an overemphasis on demonstrating the link between ICT and development. She claims that researchers have neglected other important areas such as understanding the relationship between policies, politics and research. She proposes that three distinct streams of academic inquiry-policy studies, the interface between research and policy and the conceptualization of ICT4D research - are required to understand the motivations of policymakers and the complexity of the political context. By doing so, researchers will be in a better position to set new agendas and offer effective solutions in the context of ICT4D.

The RAPID framework suggests that the influence of policy on research is dependent upon the quality of empirical evidence offered, and as such, quality research can potentially lead to solutions to policy problems. Harris (2015) in the chapter 'The impact of research on development policy and practice: This much we know'. A Literature Review and the Implications for ICT4D' makes a counterargument that since most of research content revolves solely around academic impact, quality rarely leads to policy changes. This review of the impact of research on development policy and practice reports that information society impact research in the Global South has almost exclusively focused on the impact of ICTs without taking into account the socio-economic impact of research itself. Harris proposes that in order to reduce the disparity between research and practice, researchers ought to interact with stakeholders at varying levels to ensure that the research addresses real-world problems with the goal of producing tangible outputs, an argument echoed by others (Datta 2012).

Datta (2012) disaggregates some of RAPID's elements, finding that traditional approaches to communicating research to policymakers are inadequate. For better deliberative engagement, Datta emphasises that clarification is required during selection of stakeholders, in choosing when to engage in either downstream (topdown) or upstream (bottom-up) engagement and during the selection of appropriate methods of engagement. One example of a public engagement processes using ICTs is provided by Steibel and Estevez (2015) in their chapter 'Designing Web 2.0 tools for online public consultation'. These scholars found that the amalgamation of the different functions of Web 2.0 tools influences certain attributes of the political communication environment. These scholars studied two virtual public consultation spaces in Brazil using three theoretical models of online democratic communication and concluded that the design of the ICT platform would have a great influence on the public's political deliberation and discourse.

As the policy formation actors have diversified and newer channels a created, thereby making bottom-up approaches more possible, Datta suggests that the tradi- 
tional linear model of research where the results are targeted at a specific, narrow range of the audience has proved to be inadequate in modern policy engagement. Intermediaries such as the media (especially online media) have become essential in influencing people's understanding of policies and issues and can foster better understanding among stakeholders of diverse backgrounds and capacities. Zhou (2015) in his chapter 'ICTs and opinion expression: An empirical study of newgeneration migrant workers in Shanghai' examines the basic pattern and antecedents of Chinese rural-to-urban migrant workers' intentions to express themselves, finding that new media channels have become an important space for discussing problems. Zhou concludes that since the availability of online platforms and mobile phones have the ability to empower migrant workers, policymakers and social activists may get inspirations from these findings to consider designing effective campaigns via online platforms to facilitate the active opinion expression among new-generation migrant workers in China. The study also provides cautionary evidence against overdue emphasis on online media, since personal networks continue to exert the most influence among this group at the lack of a link between online behaviour and offline expressive intentions.

\subsection{Input-Mechanism-Outputs Pathway}

Chib, van Velthoven and Car (2014) review mobile health-care studies conducted in the developing world (53 studies represented by 63 papers), pointing out a lack of dominant theory or measures of outputs that are relevant to making policy decisions. They propose a categorisation through an input-mechanism-outputs pathway where inputs are issues of technology access and use, mechanisms are psychosocial influences and individual preferences, and outputs are efficiency measures such as health-care process factors or effectiveness measures such as health indicators within the beneficiary population. The analysis revealed a plethora of pilot studies, implementation evaluations or studies with undefined design or interviews; most of the studies lacked explicit theoretical support and largely failed to address impact. Chib, Leon and Rahim use the pathways model to delve into the literature on the impact of mFinance initiatives in the chapter 'The impact of mFinance initiatives: A review of the literature'. These scholars identify the notions and evidence of impact of mFinance initiatives, broadly including m-banking, $\mathrm{m}$ payments and $\mathrm{m}$-finance (Donner 2007). They examine issues such as how impact is conceptualised in the mFinance literature, what evidence exists for this impact and what alternative definitions of impact can be proposed, beyond traditional notions of economic development such as income and savings. The review of 51 research papers found that studies focused largely on explanation of mechanisms influencing adoption of mFinance. The authors however suggest that lack of the linkage between adoption processes and substantive impact on the poor might lack sufficient value for policymakers keen to support the growth of mFinance initiatives. 


\subsection{Process-Based Impact Frameworks}

Heeks and Molla (2009) offer a longitudinal framework examining the shift in research focus from readiness (issues of awareness, digital divide and supply) to availability (questions of infrastructure and capacity) to uptake (issues of demand and usage) and finally to impacts (questions of efficiency, effectiveness and equity). The Heeks and Molla's compendium (2009) proposes that the discipline moves on from talking about potential to how the actuality of 'downstream' development impact is like (not just the 'upstream' elements of accessibility and infrastructure).

Similarly, Batchelor and Norrish present a framework for ICT pilot projects which seek to go 'beyond monitoring and evaluation to applied research' (2005, p. 7). Martin Hilbert suggests a 'Cube Framework' based on observations of Latin American cases where ICTs play a significant role in gradual socio-economic evolution, while technology, policy and social change dimensions are 'interplaying' to bring such evolution in the Global South. The 'Real Access Framework' (brides.org 2005 adapted by Gomez 2008) talks about resource portfolios and the importance of larger institutional and social structures within which the research is situated.

The review of studies providing a basis for policymaking might suggest that the ICTD field has a robust theoretical and rigorous methodological tradition. There are those, however, who question the quality of impact assessments in the ICTD, critiquing both the conceptual foundations and the emphasis on descriptive case studies (Heeks 2010). In spite of the profusion of frameworks and approaches, there are common problems that crop up repeatedly. Almost all process models seem to suggest a clear dividing line between 'inputs' and 'outputs', often treating them in separate silos. There is little determination of causality, leading to some methodological issues. There's an inadequate understanding of the mechanisms of usage and interaction between the inputs and outputs mechanisms.

We may also find ourselves questioning the basic premises and assumption of development studies: Who are the marginalised and poor? Which society do we refer to when discussing the information society? Which types of data collection and analytical methods can claim superiority over others? Despite these misgivings, the data is rich and comes from far afield, often illuminating subjects and regions that are hard to come by. The material contained here helps us validate or questions existing theory, proposes new models for conceptualization and measurement and provides varied evidence for the beneficial, the constrained and the negative impacts of ICTs.

\section{Conclusion}

This chapter has introduced various aspects of the SIRCA programme-the focus on capacity building brought about by support for mentorship in the research process; the multiplicity of voices; methodologies and traditions that constitute 
development research; the role of underlying theory as a basis for investigation, validation, extension and refutation; and number of lessons we draw from the empirical evidence offered. While many of these aspects may arguably be examining the impact of research upon research itself, this volume may not only be seen as a research output. The partial value of this compendium is in allowing scholars from the Global South to learn about, interrogate and present work gleaned from their communities to a global audience, including policymakers and practitioners. One might argue that the biggest challenge faced in imagining, designing and running the SIRCA II programme was in identifying an over-arching theme to bind the disparate voices to present a coherent and comprehensive whole. I would argue instead that the value of the programme was in trusting in the process-fostering a community of emerging scholars to draw upon the expertise of established scholars and scholarship, to challenge the assumptions and findings in interdisciplinary forums, and encouraging impact beyond traditional academic output. One of the resultant outputs is in your hands, though this is not the only one.

The personal achievements of SIRCA scholars, too numerous to detail here, range from academic publications in international outlets and presentations at global conferences, appointments and promotions, admissions and employment at prestigious institutions. It is worthwhile within the context of impact on policy and practice, possibly adding a dimension of influencing public opinion via media dissemination of research results, to consider other dimensions of impact.

A number of SIRCA II PIs took their projects beyond the academic levelengaging at the policy level with local communities where their fieldwork was based, at the university level with regard to research focus and funding and with national media and policymakers at the international level, representing the research perspective in global public consultations on ICT issues. Nikos Dacanay's research helped obtain national funding for the Burma Women's Union's (BWU) citizen journalism project, which documents political and current events/stories in several parts of Burma. Ezmieralda Melissa's research was replicated at the university level (Swiss-German University, Indonesia), with the incorporation of ICT as a key research theme under the university's umbrella. Fabro Steibel's research led to collaboration with the 'Marco Civil da Internet' or the Brazilian Civil Rights Framework for the Internet. He was invited to design public consultation portals for the Ministry of Justice as well as for the human rights agency of Mercosul, culminating in selection as an independent researcher from Brazil for the global Open Government Partnership. Matías Dodel's work led to the creation of the Research Group on Uruguay, Society and Internet (GIUSI), whose mandate is to create a general analytic framework on the Internet's impact. The group is also the national chapter for the World Internet Project. Sebastián Benítez Larghi discussed his findings with policymakers at the Programa Conectar Igualdad (PCI), an institution focused on digital inclusion in Argentina, and was also invited several times to TV and radio programmes and interviewed by different news agencies and newspapers.

There is one final measure of impact-yours. Enjoy the read! 
Open Access This chapter is distributed under the terms of the Creative Commons Attribution Noncommercial License, which permits any noncommercial use, distribution, and reproduction in any medium, provided the original author(s) and source are credited.

\section{References}

Alsop, R., \& Heinsohn, N. (2005). Measuring empowerment in practice-Structuring analysis and framing indicators. Washington, DC: World Bank.

Batchelor, S., \& Norrish, P. (2005). Framework for the assessment of ICT pilot projects: Beyond monitoring and evaluation to applied research. Washington, DC: World Bank.

Bell, D. (1999). The coming of post-industrial society. New York: Basic Books.

Bhatnagar, S. C., \& Singh, N. (2010). Assessing the impact of E-government: A study of projects in India. Information Technologies and International Development, 6(2), 109-127.

Butt, D., \& Sarker, P. P. (2009). ICT for development in Asia Pacific: Emerging themes in a diverse region. In Digital review of Asia Pacific 2009-2010. Montreal: Sage Publications.

Carmody, P. (2013). A knowledge economy or an information society in Africa? Thintegration and the mobile phone revolution. Information Technology for Development, 19(1), 24-39. doi:10. 1080/02681102.2012.719859.

Carney, D. (1998). Sustainable livelihoods: What contribution can we make? London: Department for International Development.

Castells, M. (1996). The rise of the network society. Oxford: Blackwell Publishing.

Castells, M. (2000). The information age: Economy society and culture, vol. 1: The rise of the network society. Oxford: Blackwell.

Chandwani, R., \& De, R. (2015). The institutional dynamics perspective of ICT for health initiatives in India. In A. Chib, J. May, \& R. Barrantes (Eds.), Impact of information society research in the global south. New York: Springer.

Chew, H. E., Levy, M., \& Ilavarasan, P. V. (2011). The limited impact of ICTs on microenterprise growth: A study of businesses owned by women in urban India. Information Technologies \& International Development, 7(4), 1-16.

Chib, A. (2009). The role of ICTs in nurturing the field of information and communication technologies for development. International Communication Association Newsletter, 37(2), 13-16. Available at http://www.icahdq.org/pubs/publicnewsletter/2009/3/MAR09FULLPF.asp

Chib, A., \& Harris, R. (2012). Linking research to practice: Strengthening ICT for development research capacity in Asia. Singapore: Institute of Southeast Asian Studies.

Chib, A., \& Zhao, J. (2009). Sustainability of ICT interventions: Lessons from rural projects in China and India. In L. Harter, M. J. Dutta, \& C. E. Cole (Eds.), Communicating for social impact: Engaging communication theory, research, and pedagogy (pp. 145-159). Cresskill: Hampton Press.

Chib, A., Leon, L., \& Rahim, F. (2015). The impact of mFinance initiatives: A review of the literature. In A. Chib, J. May, \& R. Barrantes (Eds.), Impact of information society research in the global south. New York: Springer.

Chib, A., van Velthoven, M., \& Car, J. (2014). mHealth adoption in low-resource environments: A review of the use of mobile healthcare in developing countries. Journal of Health Communication. doi:10.1080/10810730.2013.864735.

Cruz, E. M., \& Sajo, T. J. (2015). Cybersex as affective labour: Critical interrogation of the Philippine ICT framework and the Cybercrime Prevention Act of 2012. In A. Chib, J. May, $\&$ R. Barrantes (Eds.), Impact of information society research in the global south. New York: Springer.

Datta, A. (2012). Deliberation, dialogue and debate: Why researchers need to engage with others to address complex issues. IDS Bulletin, 43(5), 9-16. doi:10.1111/j.1759-5436.2012.00357.x. 
Djane, K. A., \& Ling, R. (2015). The use of mobile communication in the marketing of foodstuffs in Cote d'Ivoire. In A. Chib, J. May, \& R. Barrantes (Eds.), Impact of information society research in the global south. New York: Springer.

Dodel, M. (2015). An analytical framework to incorporate ICT as an independent variable. In A. Chib, J. May, \& R. Barrantes (Eds.), Impact of information society research in the global south. New York: Springer.

Donner, J. (2007). M-banking. Extending financial services to poor people. id21 insights, IDS, University of Sussex. Available at http://r4d.dfid.gov.uk/PDF/Articles/insights69.pdf

Donner, J. (2008). Research approaches to mobile phone use in the developing world: A review of literature. The Information Society, 24(3), 140-159. doi:10.1080/01972240802019970.

Elder, L., Emdon, H., Fuchs, R., \& Petrazzini, B. (Eds.). (2013). Connecting ICTs to development: The IDRC experience. London: Anthem Press.

Gandy, O. H., Jr. (2002). The real digital divide: Citizens versus consumers. In L. A. Lievrouw \& S. M. Livingstone (Eds.), The handbook of new media: Social shaping and consequences of ICTs. London: Sage.

Gomez, R. (2008). The quest for intangibles: Understanding ICTs for digital inclusion beyond socio-economic impact. Paper presented at the Prato CIRN 2008 Community Informatics conference. Prato.

Gomez, R., \& Pather, S. (2012). ICT evaluation: Are we asking the right questions? The Electronic Journal of Information Systems in Developing Countries, 50(5), 1-14.

Harris, A., \& Chib, A. (2012). Perspectives on ICTD research and practice. In A. Chib \& R. Harris (Eds.), Linking research to practice: Strengthening ICT for development research capacity in Asia (pp. 3-11). Singapore: Institute of Southeast Asian Studies.

Harris, R. (2015). The impact of research on development policy and practice: This much we know. In A. Chib, J. May, \& R. Barrantes (Eds.), Impact of information society research in the global south. New York: Springer.

Hatakka, M., \& De, R. (2011). Development, capabilities and technology: An evaluative framework. Proceedings from IFIP WG9.4: 11th international conference on Social Implications of Computers in Developing Countries. Kathmandu.

Heeks, R. (2010). Do information and communication technologies (ICTs) contribute to development? Journal of International Development, 22(5), 625-640. doi:10.1002/jid.1716.

Heeks, R., \& Molla, A. (2009). Compendium on impact assessment of ICT-for-development projects. Retrieved from https://digital.lib.washington.edu/researchworks/handle/1773/25541

Hilbert, M. (2014). Technological information inequality as an incessantly moving target: The redistribution of information and communication capacities between 1986 and 2010. Journal of the Association for Information Science and Technology, 65(4), 821-835. doi:10.1002/jid. 1716.

House, E. R. (1980). Evaluating with validity. Beverly Hills: Sage.

Hutton, W., \& Giddens, A. (Eds.). (2001). On the edge: Living with global capitalism. London: Vintage.

Kleine, D. (2010). ICT4WHAT? Using the choice framework to operationalise the capability approach to development. Journal of International Development, 22(5), 674-692. doi:10.1002/ jid.1719.

Kleine, D. (2013). Technologies of choice? ICTs, development, and the capabilities approach. Cambridge: MIT Press.

Mansell, R. (1999). New media competition and access: The scarcity-abundance dialectic. New Media and Society, 1(2), 155-182. doi:10.1177/14614449922225546.

May, J., \& Diga, K. (2015). Progress towards resolving the measurement link between ICT and poverty reduction. In A. Chib, J. May, \& R. Barrantes (Eds.), Impact of information society research in the global south. New York: Springer.

McNamara, K. S. (2003). Information and communication technologies, poverty and development: Learning from experience. Washington, DC: InfoDev, World Bank. 
Melissa, E., Hamidati, A., Saraswati, M. S., \& Flor, A. (2015). The Internet and Indonesian women entrepreneurs: Examining the impact of social media on women empowerment. In A. Chib, J. May, \& R. Barrantes (Eds.), Impact of information society research in the global south. New York: Springer.

Newton, J., \& Franklin, A. (2011). Delivering sustainable communities in China: Using a sustainable livelihoods framework for reviewing the promotion of "ecotourism" in Anji. Local Environment, 16(8), 789-806. doi:10.1080/13549839.2011.569536.

Norris, P. (2001). Digital divide: Civic engagement, information poverty, and the internet worldwide. Cambridge: Cambridge University Press.

Olivera, P., Ale, K., \& Chib, A. (2015). (Un)Balanced conversations: Participatory action research in technology development in peruvian primary schools. In A. Chib, J. May, \& R. Barrantes (Eds.), Impact of information society research in the global south. New York: Springer.

Ordóñez, A. (2015). A new set of questions: ICT4D research and policy. In A. Chib, J. May, \& R. Barrantes (Eds.), Impact of information society research in the global south. New York: Springer.

Papert, S. (1987). Information technology and education: Computer criticism vs. technocentric thinking. Educational Researcher, 16(1), 22-30.

Parthasarathy, B., \& Srinivasan, J. (2006, October). Innovation and its social impacts: The role of ethnography in the evaluation and assessment of ICTD projects. Paper presented at the Global Network for Economics of Learning, Innovation, and Competence Building Systems conference, Trivandrum.

Qureshi, S. (2005). How does information technology affect development? Integrating theory and practice into a process model. Proceedings from the 11th Americas conference on Information Systems. Omaha.

Rantanen, T. (2001). The old and the new: Communication technology and globalization in Russia. New Media and Society, 3(2), 85-105.

Reimer, B. (2002). Understanding and measuring social capital and social cohesion. Montreal: Concordia University, Canadian Rural Restructuring Foundation.

Rodriguez, P. P., Nussbaum, M. M., \& Dombrovskaia, L. L. (2012). Evolutionary development: A model for the design, implementation, and evaluation of ICT for education programmes. Journal of Computer Assisted Learning, 28(2), 81-98.

Scoones, I. (1998). Sustainable rural livelihoods: A framework for analysis (unpublished paper). Brighton: University of Sussex Institute of Development Studies.

Selwyn, N. (2010). Degrees of digital division: Reconsidering digital inequalities and contemporary higher education. RUSC. Universities and Knowledge Society Journal, 7(1). http://dx.doi. org/10.7238/rusc.v7i1.660.

Sen, A. (1999). Development as freedom. New York: Oxford University Press.

Shapiro, C., \& Varian, H. R. (1999). Information rules: A strategic guide to the network economy. Boston: Harvard Business School Press.

Sinha, C., Elder, L., \& Smith, M. (2012). SIRCA: An opportunity to build and improve the field of ICT4D. In A. Chib \& R. Harris (Eds.), Linking research to practice: Strengthening ICT for development research capacity in Asia (pp. 12-24). Singapore: Institute of Southeast Asian Studies.

Steibel, F., \& Estevez, E. (2015). Designing Web 2.0 tools for online public consultation. In A. Chib, J. May, \& R. Barrantes (Eds.), Impact of information society research in the global south. New York: Springer.

Taylor, R., \& Zhang. B. (2007, September). Measuring the impact of ICT: Theories of information and development. Paper presented at the Telecommunications Policy Research conference, Washington, DC.

van Rijn, F., Burger, K., \& den Belder, E. (2012). Impact assessment in the sustainable livelihood framework. Development in Practice, 22(7), 1019-1035. doi:10.1080/096/4524.2012.696586.

Warschauer, M. (2003). Dissecting the 'digital divide': A case study in Egypt. The Information Society, 19(4), 297-304. doi:10.1080/01972240309490. 
Waverman, L., Meschi, M., \& Fuss, M. (2005). The impact of telecoms on economic growth in developing countries. The Vodafone Policy Paper Series, 2(03), 10-24.

Young, J., \& Court, J. (2004). Bridging research and policy in international development: An analytical and practical framework. Retrieved from http://www.odi.org/publications/159bridging-research-policy-international-development-analytical-practical-framework

Zhou, B. (2015). ICTs and opinion expression: An empirical study of new-generation migrant workers in Shanghai. In A. Chib, J. May, \& R. Barrantes (Eds.), Impact of information society research in the global south. New York: Springer. 